\title{
Література:
}

1. Савенко А. И. Великая церковь Киево-Печерской лавры. Киев, 1901. $41 \mathrm{c}$.

2. КПЛ-А-402. Копії договорів Духовного Собору КиєвоПечерського монастиря 3 художниками С. Лазарєвим-Станищевим, В. Фартусовим, Г. Поповим, А. Лаковим про роботи по розпису стін Успенського собору і Трапезної церкви (стін та іконостаса) КиєвоПечерського монастиря. 1894-1907. 29 арк.

3. Уманцев Ф. Матеріали до словника вітчизняних мистців, ремісників, керівників художніх робіт та меценатів XVIII - початку $\mathrm{XX}$ ст. (за документами архіву Києво-Печерської лаври). Студіï мистецтвознавчі / Ін-т мистецтвознав., фольклористики та етнології ім. М.Т.Рильського. Чис. 1 (21). 2008. С. 102-129.

4. Шиденко В. А. Вибрані праці з історії Києво-Печерської лаври. Київ, 2008. 254 с.

5. Крайня О. О. До історії монументального розпису Успенського собору кінця XIX ст. Велика Успенська церква Києво-Печерської лаври. Слiд y віках : матеріали міжнар. наук. конф. (м. Київ, 1-2 жовтня 2001 р.) / НКПІКЗ. Київ, 2002. С. 111-120.

6. Петров Н. О новом расписании стен великой церкви Киево-Печерской лавры. Труды Киевской Духовной Академии. 1901. № 2. С. 277-296.

DOI https://doi.org/10.30525/978-9934-26-117-6-32

\section{МЕТОД РЕПРЕЗЕНТАЦІї ЖІНОЧНОСТІ У ТВОРАХ Ф. Н. СОУЗИ}

\author{
Горбачова В. В. \\ аспірант кафедри теорії та історії мистецтв \\ Харківська державна академія дизайну та мистецттв \\ м. Харків, Україна
}

Френсіс Ньютон Соуза - один 3 найвпливовіших сучасних індійських митців. Його творчий доробок поєднує у собі особливість традиційного індійського мистецтва та свободу експерименту, що поширювалась серед європейських митців XX ст. Протягом своєї шестидесятирічної кар'єри Соуза експериментував з низкою жанрів та стилів, але звичайно найбільшу увагу здобула його потужна фігуративна 
практика, лінійні малюнки та серії «чорних картин», створених у Лондоні в 50-60-х роках XX ст.

На початку своєї міжнародної популярності митець був співзасновником «Прогресивної мистецької групи» (англійською Bombay Progressive Artists' Group). Вона припинила своє існування після того, як декілька їі членів поїхали на навчання у Європу. Головною метою «ПМГ» було синтезувати традиції національного мистецтва із сучасними європейськими та американськими мистецькими рухами, черпаючи основне натхнення з давньоіндійських мистецьких традицій. Саме тому в різні часи мистецтвознавці зустрічають у творчості Ф. Н. Соузи натхнення європейськими художниками, включаючи Тиціана, Едуарда Мане, Анрі Матіса, Пікассо, Гойю та багатьох інших [1, с. 27].

Окремим важливим контрапунктом у творчості митця стає звернення до релігійних образів. Від народження він був пов'язаний 3 християнською традицією, адже частина дитинства пройшла на Гоа, який на той час був португальською католицькою колонією. Після переїзду до Бомбею Ф. Соуза відвідував школу під керівництвом монахів єзуїтів. У 1949 році митець взагалі вирушив до Лондона. Саме тому християнська складова знову і знову буде з'являтись у творах митця у формі відомих в історії мистецтв сюжетів.

Також протягом своєї кар'єри Ф. Соуза створює численні образи оголених жінок, акцентуючи увагу на виразній чуттєвості та еротичності пози. Зазвичай він надавав перевагу важкій структурі тіла зі збільшеними статевими органами та дивними обличчями. Наприклад. у роботі «Три жінки» (1949р.) Соуза відтворив фігури у позах скульптури храму Кхаджурахо [3, с. 154]. Ці три образи цілком схожі на якші, жіночі фігури духів, що зустрічаються у храмах Матхури та Кхаджурахо. Зображеним фігурам властива грація й відсутність сором'язливості. Цікавість митця, майже одержимість Соузи оголеними жіночими образами, постійно обговорювалась численними критиками та художниками. За деякими підрахунками митець зробив приблизно 12000 еротичних ескізів.

$\Phi$. Соуза частіше за все перетворює зображену жінку на предмет. На деяких картинах він часто збільшував розміри статевих органів, тим самим підкреслюючи спокусу. Інші твори демонструють глядачу привабливе обличчя молодої дівчини, що виглядає досить маленьким у порівнянні з тілом та неприродньо великими грудьми, - вона нагадує первісні зображення, палеолітичних венер. Частина малюнків створена чорнилами на папері. Тоді образ жінки, хоч і полишається вільним від будь-яких соціальних кордонів, завдяки сміливому фронтальному погляду, але привертає увагу своєю емоційністю і виразністю лінії. 
Що стосується зображення жінки, то краса та чарівність - найбільш змальований аспект індійських картин 3 найдавніших часів. Ф. Соуза, навпаки, спотворював це сприйняття краси та викреслював стереотип сором'язливої, скромної жінки. Митець створював демонічні фігури, які навпаки далекі від таких благородних чеснот; вони просто такі, якими вони $\epsilon$, або якими їх створив художник.

У цьому контексті мистецтво репрезентації просто базується на сприйнятті спочатку художника, а потім глядачів. В Індії дуже довго зображення жінки робилося на основі деяких заздалегідь вирішених аспектів, знайдених у книгах і трактатах, наприклад, «Чітрасутрі», що розкриває основи давнього індійського мистецтва. Згідно 3 цими сутрами, жінка повинна бути красивою, пропорційною і сповненою делікатності. Цих ідеалів зображення жінки дотримувались і $з$ найдавніших часів до XIX ст. аж потім деякі сучасні художники, такі як Амріта Шер-Гіл, Джаміні Рой, Рабіндранат Тагор не представили інший погляд. У цьому контексті не можна не помітити роль А. Шер-Гіл, яка представляє сільських жінок із їхніми сумними обличчями у ман'єристичному стилі [3, с. 202]. Вона, мабуть, перша та найвизначніша художниця, яка порушила серйозність проблеми життя жінки в індійському суспільстві XX ст.

Згодом численні художники експериментували із зображеннями жінок відповідно до власних стилів та підходів, але у випадку 3 Френсісом Соузою зображення жінок в основному робилося для того, щоб викрити іiі потяг до еротичних бажань. Такого роду жінка не зображувалась раніше в історії індійського живопису. Жінка на картині Соузи не $\epsilon$ красивою чи пропорційною; вона дуже драматизована і відчайдушно запрошує до кохання.

Фактично, своїми роботами митець ініціював власну розповідь про красу жіночого образу, виділяючи в першу чергу статеві органи, а не чарівність та привабливість обличчя. Між тим. Критика порнографічності робіт митця зіштовхується також з ідеальним ритмом кольорової аплікації та ліричної гармонії зображення, нехай і з сарказмом.

Численні роботи Ф. Н. Соузи створювались під впливом робіт видатних західних художників паризької школи. Вплив Пабло Пікассо можна побачити на більшості портретах. Пікассо написав багато жіночих портретів, на яких обличчя дивним чином поділяються на деякі спотворені форми. Митець підхоплюе цю техніку, використовуючи яскраві кольори та потужні штрихи.

Тягу до еротизму можна пояснити двома концепціями. Х одного боку, це може бути спробою художника вгамувати власний психологічний неспокій. Звичайно, зображення фемінного образу на 
картинах Ф. Соузи може бути відображенням його негативного i позитивного ставлення до жінки. X іншого боку, занадто еротичні зображення можуть підходом до критики ортодоксального суспільства, оскільки як художник він мав свободу висловлювати свої погляди у будь-якій манері.

Підхід Ф. Соузи є досить соціально-політичним та ексклюзивним сам по собі, адже жінка для нього - це інструмент за допомогою якого можно коли відобразити граничну гіркоту ії становища у суспільстві. Хоча він був шанувальником еротичного та нового підходу індійського та європейського мистецтва, його більше влаштовувало пишне та чуттєве жіноче тіло індійських храмових образів. Але й на цьому не завершуються експерименти автора, адже на полотнах митця йде знехтування репродуктивним аспектом жіночності, і все одно домінує сексуальність із порочністю.

\title{
Література:
}

1. Bhattacharya K. S. Trends in Modern Indian Art. M.D. India, 1994. $94 \mathrm{p}$.

2. Parimoo Ratan Progressive Artists Group of Bombay: An Overview URL: http://www.artnewsnviews.com/view-article.php?article=progressiveartists-group-of-bombay-an-overview\&iid $=29 \&$ articleid $=800$

3. Partha Mitter The Triumph of Modernism. India's Artists and the Avant-garde, 1922-47. London, 2007. - 272 p., il.

\section{DOI https://doi.org/10.30525/978-9934-26-117-6-33}

\section{РАННЬОХРИСТИЯНСЬКІ СИМВОЛИ ІСУСА ХРИСТА ТА ЇХ ЗНАЧЕННЯ}

\author{
Дем'янчук А. Л. \\ кандидат мистеитвознавства, \\ доцент кафедри режисури і хореографії \\ Львівський нащіональний університет імені Івана Франка \\ м. Львів, Україна
}

Перші сакральні символи та речові атрибути ранніх християнських богослужінь знаходимо в Єрусалимі, адже там відбулися євангельські події - Розп'яття та Воскресіння Ісуса Христа. Проте зруйнування та спалення Єрусалима римським військом під проводом полководця Тита 